\title{
Compression directions north of the San Fernando Valley determined from borehole breakouts
}

\author{
Stacy Kerkela ${ }^{1}$ and Joann M. Stock \\ Seismological Laboratory, California Institute of Technology, Pasadena
}

\begin{abstract}
Borehole breakouts in 4 nearly vertical oil wells, and several other deviated holes, in the San Fernando Valley and Santa Susana Mountains suggest a maximum horizontal compressive stress direction $\left(\mathrm{S}_{\mathrm{H}}\right)$ of $\mathrm{N} 49^{\circ} \mathrm{W}$. These wells provide information about the stress field from 1974 to 1983 in the uppermost crust ( $<3 \mathrm{~km}$ depth) near the aftershock zones of the January 1994 Northridge earthquake and the February 1971 Sylmar earthquake. This direction of $\mathrm{S}_{\mathrm{H}}$ is anomalous with respect to the $N$ to NNE directions of $S_{H}$ seen in other regional data, but is consistent with the structural complexity of this zone, including local changes in strike of major thrust fault zones and the presence of lateral ramps in both the Santa Susana and San Fernando faults.
\end{abstract}

\section{Introduction}

Oriented dual caliper logs accompanying 4-arm dipmeter logs can constrain the orientations of the principal stresses, as borehole breakouts (elliptical wellbore spalling) form centered at the azimuth of maximum compressive stress at the borehole wall. The major axis of the breakout ellipse in a vertical borehole is parallel to $S_{h}$, the minimum horizontal compressive stress, and the minor axis is parallel to $S_{H}$ the maximum horizontal compressive stress. $S_{h}$ and $S_{H}$ are also principal stresses, if one of the principal stresses is vertical. Vertical wells are commonly analyzed to determine the directions of the principal horizontal stresses with the assumption that one of the principal stresses is vertical $\left(\mathrm{S}_{\mathrm{v}}\right)$. The results have been shown to be consistent with other indicators of stress direction (e.g., Zoback, 1992). This result is less constrained in a thrust faulting system (Qian and Pedersen, 1991).

Breakout orientations from non-vertical drill holes can also be used to constrain the stress state, and yield relative magnitudes and directions of the three principal stresses, if enough borehole orientations are available. This is due to the fact that when the borehole is not aligned with a principal stress axis, the breakout orientation will depend on the relative magnitude and orientations of all three principal stresses (e.g., Mastin, 1988; Zajac and Stock, 1992; Brudy and Zoback, 1993). This general concept has been used to predict breakout orientations, induced fracture orientations, and borehole stability in boreholes arbitrarily inclined to the stress field (e.g., Peska and Zoback, 1995).

\section{Borehole Measurements and Data Analysis}

Our criteria for identifying borehole breakouts from 4-arm oriented dipmeter data, modified from Plumb and Hickman (1985), are as follows:

\footnotetext{
${ }^{\text {T}}$ Now at Department of Geophysics, Stanford University, Stanford, California.

Copyright 1996 by the American Geophysical Union.

Paper number 96GL03054.

0094-8534/96/96GL-03054\$05.00
}

1) The tool rotation stops in the zone of elongation.

2) The caliper arm difference exceeds 0.5 inches $(1.3 \mathrm{~cm})$.

3) The smaller of the caliper readings is close to bit size (within $5 \%$ of bit size).

4) The breakout zone is longer than 10 feet $(3.05 \mathrm{~m})$.

5) The directions of elongation should not consistently co-

incide with the azimuth of the high and low sides of the borehole when the hole deviates from vertical.

The first criterion locates sections of well where the caliper was prevented from rotating, presumably due to the friction of contact with the wall of the borehole in the zone of elongation. The second criterion applies the fact that the breakout must exceed a certain size in order to halt tool rotation. The third criterion removes sections of well where the tool was off center or the hole was washed out. The fourth criterion accounts for the inability of the tool to detect breakouts smaller than the pad length. The fifth criterion eliminates wells where the tool may have scraped along the low side of an inclined borehole, digging its own elliptical channel (a "key seat"). We applied this criterion on a case-by-case basis, because in thrust faulting stress regimes, breakouts would be expected to form on the high and low sides of deviated boreholes.

Once the inappropriate data have been eliminated, the calculation of breakout orientation is relatively straightforward. The breakout azimuth is assumed to coincide with the orientation of the larger caliper arm (e.g., Plumb and Hickman, 1985), and is defined to be in the range $0-180^{\circ}$.

\section{Analysis of Data}

We applied our technique to 10 wells in and northwest of the San Fernando Valley, California, near the aftershock zone of the 1971 and 1994 earthquakes. These wells lie in a 144 sq.

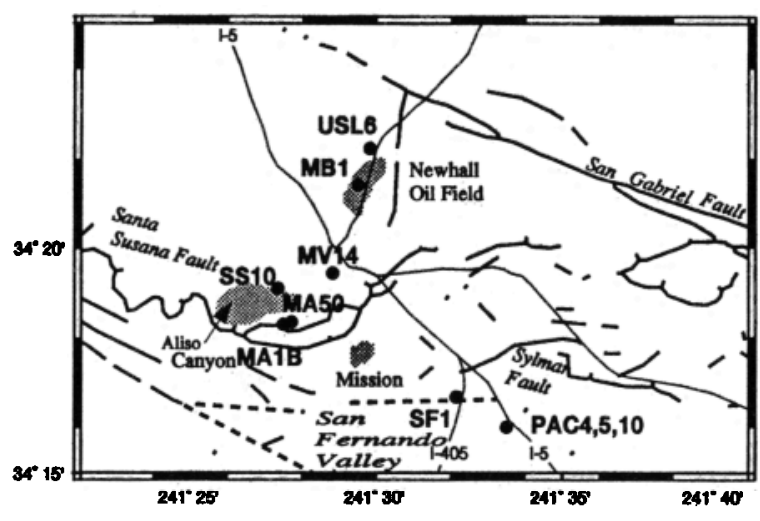

Figure 1. Map of San Fernando Valley, Santa Susana Mountains, and western San Gabriel Mountains in the region $118^{\circ} 20^{\prime}-118^{\circ} 40^{\prime}, 34^{\circ} 15^{\prime}-34^{\circ} 25^{\prime}$, showing the locations of drill holes used in this study (black dots). Major surface faults (thick black lines) are simplified from Yeats (1987) and Barrows et al. (1975). Major freeways (thin black lines) and some oil fields are labeled for reference. 


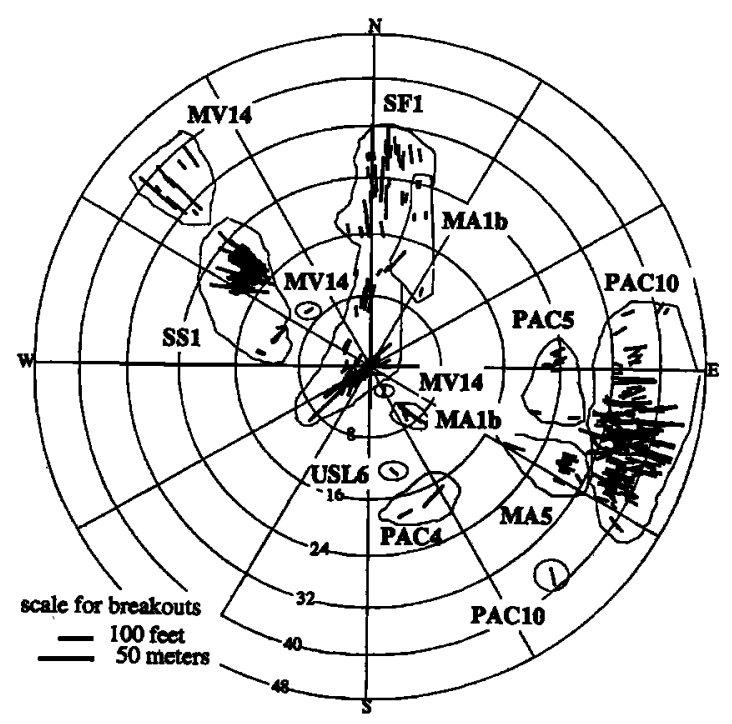

Figure 2. Lower hemisphere stereographic projection of all borehole elongation zones (breakouts) identified from the boreholes studied. Breakouts are plotted with a line parallel to their trend in map view, at the location on the stereonet which corresponds to the trend and plunge of that segment of the borehole. The length of the line representing the breakout is proportional to the length of the breakout, according to the scale given at lower left. Note that stereographic projection only goes out to $48^{\circ}$ from vertical. One breakout from borehole USL6 lies near the origin of the plot and is not individually labeled due to lack of space. Borehole elongations for holes deviated $>20^{\circ}$ may be caused by tool drag, not breakouts.

mile (373 sq. $\mathrm{km}$ ) region $\mathrm{T} 2 \mathrm{~N}-3 \mathrm{~N}, \mathrm{R} 15 \mathrm{~W}-16 \mathrm{~W}$ over a depth range of 200 to 10,000 feet $(61$ to $3048 \mathrm{~m}$ ). This region contains approximately 800 drill holes, but very few of them had the oriented dual caliper logs needed for this analysis.

These data were all collected between 1974 and 1983. These wells are from the Aliso Canyon, Mission, Placerita, Newhall, Cascade, and Pacoima oil fields, and the San Fernando Area, at approximately $34^{\circ} 15^{\prime} \mathrm{N}, 118^{\circ} 30^{\prime} \mathrm{W}$ (Fig. 1). They provide information about the stress direction from the upper plate, and within the aftershock region, of the 1994 Northridge and 1971 Sylmar earthquakes.

Paper logs for 3 wells were obtained from the Southern California Gas Company, and the remainder of the data came from the State Department of Conservation, Division of Oil and Gas archives. These paper logs were digitized and the best fitting ellipse for the borehole shape was found for every foot of data. A value of $15.9^{\circ}$ was used for the magnetic declination, to correct the observations to geographic north. Breakouts were then identified according to the criteria described above. Figures in the electronic supplement show borehole caliper readings and positions of the identified breakouts.

\section{Discussion of the Data}

The data are plotted on lower hemisphere stereographic projections in which the breakout azimuth is plotted as a line, centered on the stereonet position corresponding to the borehole trend and plunge (Fig. 2). Very few of the boreholes had trends into the SW quadrant. Most of the boreholes studied had plunges toward the NW and N or in the SE quadrant. Borehole deviations at the locations of the identified breakouts ranged from 0 to $45^{\circ}$.

The majority of the breakouts (87\%) were identified from three of the boreholes (Unocal San Fernando 1-9, Southern California Gas Aliso Canyon SFZU SS (Standard Sesnon) 1, and Chevron Pacoima 10) (Table 1). These data can be subdivided into near-vertical ( $<5^{\circ}$ deviation) and non-vertical $\left(>5^{\circ}\right.$ deviation) sections of boreholes.

The data from near-vertical drill holes are most commonly used to constrain the directions of the horizontal principal stresses. Data for holes with deviations $\leq 5^{\circ}$, comprising segments of Southern California Gas Aliso Canyon SFZU SS 1 ("SS1"), McCulloch Cascade Mission Visco 14 ("MV14"), Unocal San Fernando 1-9 ("SF1"), and Chevron Placerita USL 6 ("USL6"), are summarized in Fig. 3 and Table 1. These show a breakout azimuth averaging $\mathrm{N} 41^{\circ} \mathrm{E}$. If the principal stresses are horizontal and vertical, this implies a minimum compressive stress direction $\left(S_{h}\right)$ of $N 41^{\circ} \mathrm{E}$ and a maximum compressive stress direction $\left(\mathrm{S}_{\mathrm{H}}\right)$ of $\mathrm{N} 49^{\circ} \mathrm{W}$. This result is dominated by the data from the SF1 borehole but also agrees with breakouts from near-vertical sections of SS1.

A similar NE breakout direction also occurs in drill hole segments with deviations between $5^{\circ}$ and $16^{\circ}$ (e.g., SS1, MV14, Pac4 in Fig. 2), with the exception of a small group of data from MA1b, SS1, and USL6. Although the data from holes with deviations exceeding $5^{\circ}$ are not used in the average to determine the $S_{H}$ direction, they indicate a consistency to this stress pattern in many of the drill holes.

The elongation directions from drill holes with deviations exceeding $16^{\circ}$ are predominantly radial when plotted on the stereonet (i.e., along the high and low sides of the borehole). This direction of borehole elongation could be caused by tool drag on the bottom of a hole (a "key seat"), but is also the expected orientation of breakouts in thrust faulting or certain strike slip faulting stress regimes (Fig. 4; see also Qian and Pedersen, 1991). If these elongation directions in our more deviated holes are breakouts, they suggest a thrust faulting stress regime with $\phi,\left(S_{2}-S_{3}\right) /\left(S_{1}-S_{3}\right)$, of $\sim 0.9$ (Fig. 4). Borehole televiewer data would be able to distinguish between tensile fractures and key seats (Peska and Zoback, 1995).

Table 1. Average breakout orientations for each drill hole

\begin{tabular}{|c|c|c|c|c|c|c|c|c|c|c|}
\hline Operator & Field & Well Name & $\begin{array}{l}\text { Breakout } \\
\text { Azimuth } \\
\text { ( }{ }^{\circ} \text { East } \\
\text { of North) }\end{array}$ & $\begin{array}{l}\text { Breakout } \\
\text { Length } \\
\text { (ft) }\end{array}$ & (m) & $\begin{array}{l}\sigma \text { of } \\
\text { Mean } \\
\left(\left(^{\circ}\right)\right.\end{array}$ & $\begin{array}{l}\text { Township/ } \\
\text { Range }\end{array}$ & Section & $\begin{array}{l}\text { Depth Range } \\
\text { of Breakouts } \\
\text { (ft) }\end{array}$ & (m) \\
\hline $\begin{array}{l}\text { S. Calif Gas } \\
\text { S. Calif. Gas } \\
\text { Chevron } \\
\text { McCulloch } \\
\text { Chevron } \\
\text { Chevron } \\
\text { Chevron } \\
\text { Unocal } \\
\text { S. Calif. Gas } \\
\text { Chevron } \\
\text { All segments }\end{array}$ & $\begin{array}{l}\text { Aliso Canyon } \\
\text { Aliso Canyon } \\
\text { Elsmere } \\
\text { Cascade } \\
\text { Pacoima } \\
\text { Pacoima } \\
\text { Pacoima } \\
\text { San Fernando Area } \\
\text { Aliso Canyon } \\
\text { Placenta } \\
\text { th borehole deviation }\end{array}$ & $\begin{array}{l}\text { SFZU MA lb } \\
\text { SFZU MA 5-0 } \\
\text { Margaret Bath 1 } \\
\text { Mission Visco } 14 \\
\text { Pacoima } 10 \\
\text { Pacoima } 4 \\
\text { Pacoima } 5 \\
\text { San Fernando 1-9 } \\
\text { SFZU SS 1-0 } \\
\text { USL } 6 \\
5^{\circ}\end{array}$ & $\begin{array}{l}-25.7988 \\
-71.102 \\
\\
-43.7411 \\
-82.9356 \\
51.0707 \\
76.9564 \\
25.6176 \\
-687491 \\
-29.5303 \\
43.1183\end{array}$ & $\begin{array}{l}278 \\
228 \\
\text { none found } \\
348 \\
3814 \\
196 \\
149 \\
2464 \\
2313 \\
26 \\
1665\end{array}$ & $\begin{array}{l}84.73 \\
69.49 \\
\\
106.07 \\
1162.51 \\
59.74 \\
45.42 \\
751.21 \\
705.00 \\
7.92 \\
507.49\end{array}$ & $\begin{array}{l}0.666101 \\
0.17651 \\
\\
0.271471 \\
0.34839 \\
0.229556 \\
0.171917 \\
0.497287 \\
0.36233 \\
0.39711 \\
0.377041\end{array}$ & $\begin{array}{l}3 \mathrm{~N} / 16 \mathrm{~W} \\
3 \mathrm{~N} / 16 \mathrm{~W} \\
3 \mathrm{~N} / 16 \mathrm{~W} \\
3 \mathrm{~N} / 16 \mathrm{~W} \\
2 \mathrm{~N} / 15 \mathrm{~W} \\
2 \mathrm{~N} / 15 \mathrm{~W} \\
2 \mathrm{~N} / 15 \mathrm{~W} \\
2 \mathrm{~N} / 15 \mathrm{~W} \\
3 \mathrm{~N} / 16 \mathrm{~W} \\
3 \mathrm{~N} / 16 \mathrm{~W}\end{array}$ & $\begin{array}{l}34 \\
34 \\
12 \\
25 \\
15 \\
15 \\
15 \\
09 \\
28 \\
01\end{array}$ & $\begin{array}{l}2139-3838 \\
3524-8091 \\
(233-1495 \\
1037-2790 \\
2100-10404 \\
4625-8229 \\
2562-6050 \\
240-7400 \\
4595-9822 \\
248-1070\end{array}$ & $\begin{array}{l}316-850 \\
640-3171 \\
1410-2508 \\
781-1844 \\
73-2256 \\
1401-2994 \\
76-326\end{array}$ \\
\hline
\end{tabular}

* depth range of well log 
(a)

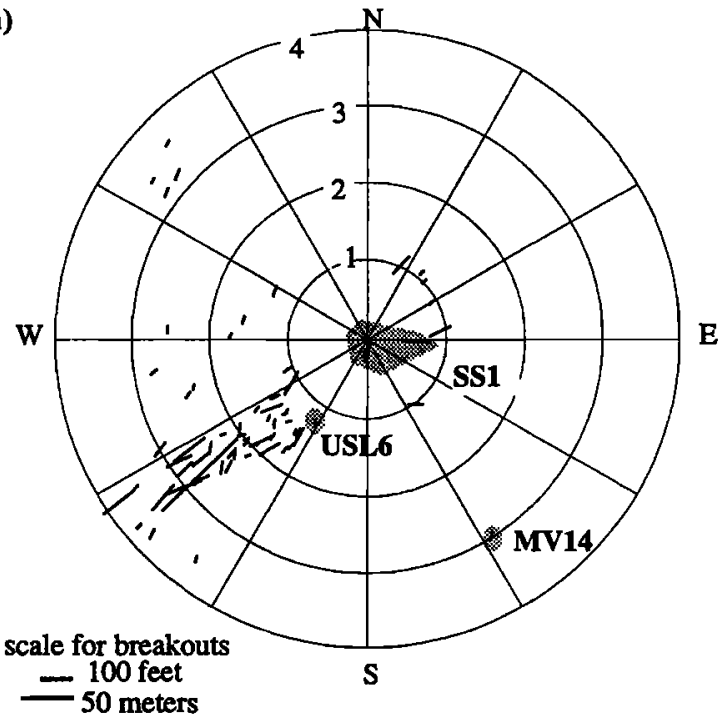

(b)

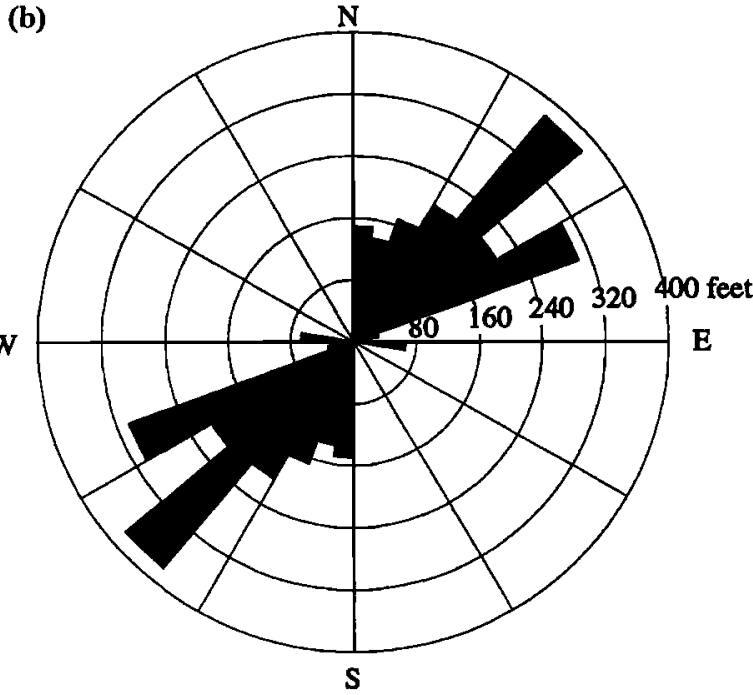

Figure 3. (a) Lower hemisphere stereographic projection of breakouts from near-vertical holes (deviation $<5^{\circ}$ ). Plotting conventions and scale are the same as in Figure 2. Note that the projection only goes out to $5^{\circ}$ from vertical. The majority of the data are from the San Fernando 1 borehole; data from the holes SS1, USL6, and MV14 are within the shaded regions. (b) Rose diagram for same data, showing dominant NE trend of breakouts. Data are grouped in $10^{\circ}$ increments of breakout azimuth.

\section{Comparison with Other Stress Field Data}

A comparison of the breakout observations with other stress field data, and with regional structural trends, suggests considerable small-scale heterogeneity in the stress directions in this region. Our results suggest that, at least at shallow depths $(<2 \mathrm{~km})$, in the nearly vertical drill holes from the region, the $\mathrm{S}_{\mathrm{H}}$ direction was roughly NW-SE. These wells all lie in a zone where the major active thrust faults, such as the Santa Susana and Mission Hills Faults, locally strike NE. For example, the Mission Visco 14 hole lies within the Cascade oil field at the position of the NE-striking, NW-dipping "Chatsworth lateral ramp" (Huftile and Yeats, 1996) in the generally N- or NE-dipping Santa Susana fault zone. A similar NNE-trending lateral ramp in the $\mathrm{N}$-dipping San Fernando fault zone lies slightly east of the wells studied. The deepening of the San Fernando fault zone on the west side of the ramp, and consequent occurrence of left-lateral strike-slip earthquakes along the ramp, were first identified in the aftershocks of the 1971
Sylmar earthquake (Allen et al., 1972). Perhaps, these lateral ramps cause local spatial variation in the stress field such that $\mathrm{S}_{\mathrm{H}}$ is at a high angle to the ramps (e.g., NW-trending).

However, more regional data suggest a $\mathrm{N}$ to $\mathrm{NNE}$ direction of $\mathrm{S}_{\mathrm{H}}$. The 1994 Northridge earthquake was a reverse faulting event with slip direction slightly $\mathrm{E}$ of $\mathrm{N}$ (Mori et al., 1995; Hauksson et al., 1995). Focal mechanisms of aftershocks from this earthquake, obtained from the Southern California Earthquake Catalog, were inverted to find principal stresses using the method of Michael (1984) (Fig. 5). The value of $\phi$ was uniformly low (less than 0.3 ), and the stress regime changed from strike slip faulting at shallow depths to thrust faulting below $6 \mathrm{~km}$. The principal stresses were near horizontal and vertical, with $\mathrm{S}_{\mathrm{H}}$ oriented from $\mathrm{N} 10^{\circ} \mathrm{E}$, above $2 \mathrm{~km}$, to $\mathrm{N} 20^{\circ} \mathrm{E}$ below $6 \mathrm{~km}$ (Table 2 in electronic supplement). This is $60-70^{\circ}$ clockwise of the direction seen in the borehole data.

The 1971 Sylmar quake was an obliquely sinistral reverse faulting event; inversion of focal mechanisms of its aftershocks indicates a thrust faulting stress regime with $\sigma_{1}$ approximately

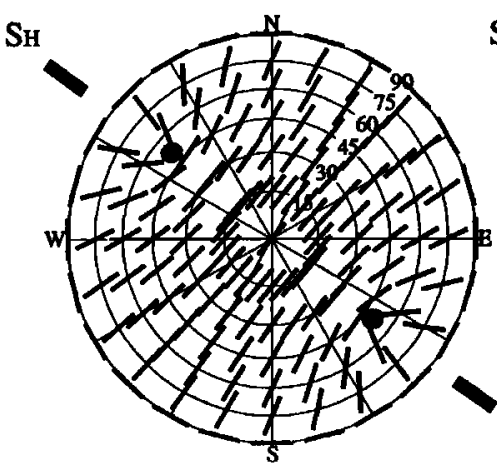

$\Phi=0.5$

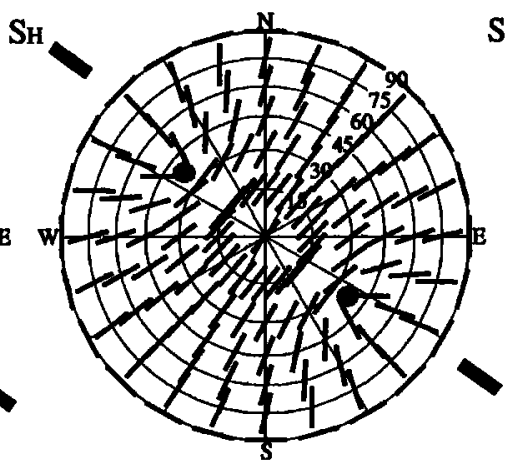

$\Phi=0.7$

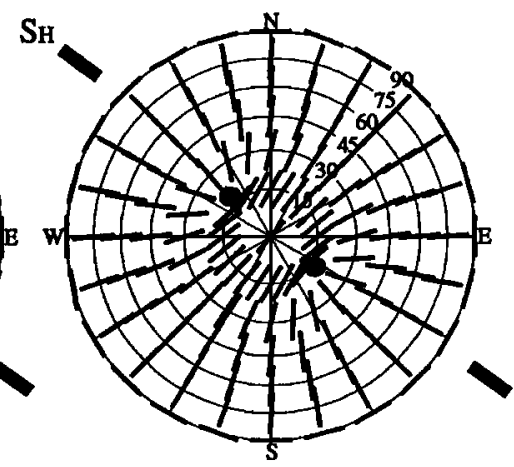

$\Phi=0.9$

Figure 4. Theoretically expected breakout patterns for a thrust faulting stress regime with $\mathrm{S}_{\mathrm{H}}$ at $\mathrm{N} 49^{\circ} \mathrm{W}$ and $\phi$ values ranging from 0.5 to 0.9. Plotting conventions are the same as in Fig. 2 except entire stereonet is shown (out to $90^{\circ}$ from vertical). Heavy black lines are expected directions of breakouts; black dots are nodal points, corresponding to borehole orientations where breakouts are less likely to form but if they do form, their azimuth would vary rapidly with small changes in borehole orientation. Poisson's ratio is assumed to be 0.25 . Note that for $\phi=0.9$, the pattern of breakouts is expected to be radial for borehole deviations greater than about $20^{\circ}$, similar to the observations in this data set. 


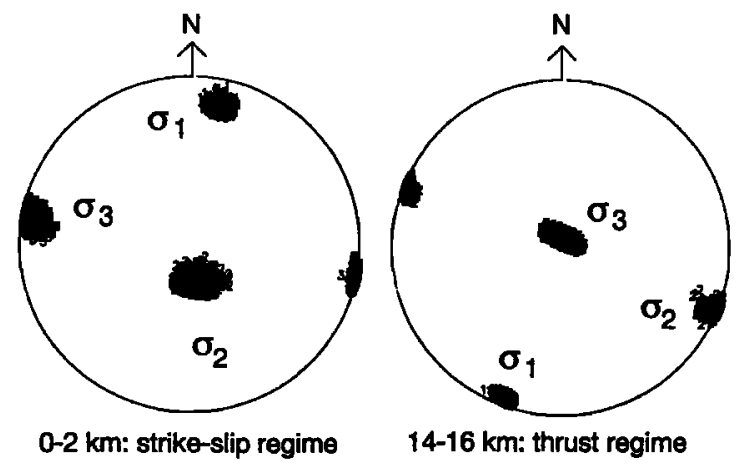

Figure 5. $95 \%$ confidence values for the three principal stresses from inversion of aftershocks, above $2 \mathrm{~km}$, larger than Magnitude 1, in the Northridge area from $1 / 17 / 94$ to $9 / 30 / 94$. (a) Events above $2 \mathrm{~km}$ (115 aftershocks used in inversion) yield a strike slip faulting stress regime with $S_{H}$ slightly $E$ of $N$ and $\phi=0.302$. (b) Events below $14 \mathrm{~km}$ (559 aftershocks) yield a thrust faulting stress regime with $\phi=0.227$.

horizontal and trending $N$ to slightly $E$ of $N$ (Gephart and Forsyth, 1984). The direction of maximum contraction seen in GPS data NW of here is also slightly $E$ of $N$ (Donnellan et al., 1993). Borehole breakouts reported for wells farther to the west in the Ventura Basin show mainly NW to WNW elongation directions, which imply a NE to NNE direction of $S_{H}$ (Mount and Suppe, 1992; Zoback, 1992). Thus our data, from near the confluence of the Northridge and San Fernando aftershock zones, indicate a local spatial and/or temporal variation in the direction of maximum horizontal compressive stress.

It is known that active faults can cause local rotations in breakout orientations (e.g., Barton and Zoback, 1994). The wells penetrate some young fault zones, including the Santa Susana fault in the Aliso Canyon region (e.g., Lant, 1977; Yeats, 1987). We could not resolve any changes in breakout orientations near these faults, but such changes would be much clearer in borehole televiewer data than in the 4-arm caliper data available to us for this study.

\section{Conclusions}

Ten well logs collected during 1974-1983, from in and northwest of the San Fernando Valley, southern California, were digitized and processed to calculate the breakout orientation for each well at distinct depth intervals. The borehole breakouts for segments of wells deviated $<5^{\circ}$ imply a maximum compressive horizontal stress $\left(S_{H}\right)$ direction of $N 49^{\circ} \mathrm{W}$. This appears to be consistent within a small region corresponding to NE-striking lateral ramps in the major N-dipping thrust faults in the region (e.g., San Fernando fault; Santa Susana fault zone) and may not represent the regional stress direction or the direction of compression at greater depths. Borehole elongations for well deviations exceeding $20^{\circ}$ are generally parallel to the plunge of the borehole and thus do not constrain the direction of $\mathrm{S}_{\mathrm{H}}$. A NW compression direction was sought, but not found, in focal mechanisms from the 1994 Northridge earthquake sequence, some of which were fairly close to these drill holes. Inversion of shallow aftershocks from the Northridge sequence gave a strike-slip faulting stress regime, with an $\mathrm{S}_{H}$ direction of $\mathrm{N} 10^{\circ} \mathrm{E}-\mathrm{N} 20^{\circ} \mathrm{E}$ and a $\phi$ value, $\left(\mathrm{S}_{2}-\mathrm{S}_{3}\right) /\left(\mathrm{S}_{1}-\mathrm{S}_{3}\right), \leq$ 0.3 . The lack of agreement between the borehole observations and the stress field indicated by the shallow Northridge aftershocks may indicate a temporal change in the stress field in this region between 1983 and 1994. Alternatively, the borehole observations may reflect a localized stress field not ob-

Supplementary data and figures are available on diskette or via Anonymous FTP from kosmos.agu.org, directory APEND (Username=anonymous, Password=guest). Diskette may be ordered by mail from AGU, 2000 Florida Ave., NW, Washington, DC 20009 or by phone at $800-966-2481 ; \$ 15.00$. Payment must accompany order. served in nearby focal mechanisms, similar to the observations from the Cajon Pass drill hole (Shamir and Zoback, 1992).

Acknowledgments. We thank the Southern California Gas Company for providing access to some of the data. This study was funded by Caltech SURF (Summer Undergraduate Research Fellowship) program and by the Southern California Earthquake Center (NSF Grant EAR-8920136). We thank Colleen Barton, Mike Bruno, and Bob Yeats for very helpful reviews of this paper. SCEC Publication number 342. Contribution Number 5577, Caltech Seismological Laboratory.

\section{REFERENCES}

Allen, C. R., T. C. Hanks, and J. H. Whitcomb, Seismological studies of the San Fernando earthquake and their tectonic implications, Calif. Div. Mines and Geology Bulletin, 196, ch. 20, pp. 257-262, 1972.

Barrows, A. G., J. E. Kahle, R. B. Saul, and F. H. Weber, Jr., Geologic map of the San Fernando earthquake area, Calif. Div. Mines and Geology Bulletin, 196, Plate 2, 1975.

Barton, C. A., and M. D. Zoback, Stress perturbations associated with active faults penetrated by boreholes - possible evidence for nearcomplete stress drop and a new technique for stress magnitude measurements, J. Geophys. Res., 99, 9373-9390, 1994.

Brudy, M., and M. D. Zoback, Compressive and tensile failure of boreholes arbitrarily inclined to principal stress axes - application to the KTB boreholes, Germany, Int. J. Rock Mech., 30, 1035-1038, 1993.

Donnellan, A., B. H. Hager, R. W. King, and T. A. Herring, Geodetic measurement of deformation in the Ventura Basin region, Southern California, J. Geophys. Res., 78, 21,727-21,739, 1993.

Gephart, J. W., and D. W. Forsyth, An improved method for determining the regional stress tensor using earthquake focal mechanism data: Application to the San Fernando Earthquake sequence, J. Geophys. Res., 89, 9305-9320, 1984.

Hauksson, E., L. M. Jones, and K. Hutton, The 1994 Northridge earthquake sequence in California - seismological and tectonic Aspects, $J$. Geophys. Res., 100, 12335, 1995.

Huftile, G. J., and R. S. Yeats, Deformation rates across the Placerita (Northridge $\mathrm{M}_{\mathrm{w}}=6.7$ aftershock zone) and Hopper Canyon segments of the Western Transverse Ranges deformation belt, Bull. Seismol. Soc. Am., 86, S3-S18, 1996.

Lant, K. J., Structure of the Aliso Canyon area, eastern Ventura Basin, California, M.S. Thesis, Ohio University, 79 p., 1977.

Mastin, L., Effect of borehole deviation on breakout orientation, $J$. Geophys. Res., 93, 9187-9195, 1988.

Michael, A. J., Determination of stress from slip data: Faults and folds, $J$. Geophys. Res., 89, 11517-11526, 1984.

Mori, J., D. Wald, and R. Wesson, Overlapping fault planes of the 1971 San Fernando and 1994 Northridge CA earthquakes, Geophys. Res. Lett., 22, 1033-1036, 1995.

Mount, V. and D. Suppe, Present day stress orientations adjacent to active strike-slip faults: California and Sumatra, J. Geophys. Res., 97, 11,995-12,013, 1992.

Peska, P. and M. D. Zoback, Compressive and tensile failure of inclined well bores and determination of in situ stress and rock strength, $J$. Geophys. Res., 100, 12791-12811, 1995.

Plumb, R. A., and S. H. Hickman, Stress-induced borehole elongation: A comparison between the four-arm dipmeter and the borehole televiewer in the Auburn geothermal well, J. Geophys. Res., 90, 5513$5522,1985$.

Qian, W., and L. B. Pedersen, Inversion of borehole breakout orientation data, J. Geophys. Res., 96, 20,093-20,107, 1991.

Shamir, G., and M. D. Zoback, Stress orientation profile to $3.5 \mathrm{~km}$ depth near the San Andreas fault at Cajon Pass, California, J. Geophys. Res., 97, p. 5059-5080, 1992.

Yeats, R. S., Late Cenozoic structure of the Santa Susana Fault zone, in U.S. Geol. Surv. Prof. Pap. 1339, 137-160, 1987.

Zajac, B. and J. M. Stock, Using borehole breakouts to constrain the complete stress tensor, EOS, Trans. American Geophysical Union, 73, no. 43 , p. $559,1992$.

Zoback, M. L., First- and second-order patterns of stress in the lithosphere: the world stress map project, $J$. Geophys. Res., 97, 11,703$11,728,1992$.

S. Kerkela, Department of Geophysics, Mitchell Hall, Stanford University, Stanford, CA 94305.

J. M. Stock, Seismological Laboratory, California Institute of Technology, Pasadena, CA 91125.

(Received July 11, 1995; revised July 1, 1996;

accepted August 29, 1996) 